\title{
Enhancing SMEs' Growth by Investing in Organizational Capital
}

\author{
Urban Pauli
}

\section{A B S T R A C T}

Objective: The objective of this paper is to verify the relationship between the share of investments in organizational capital (OC) within the total amount of investments and key performance indicators of SMEs.

Research Design \& Methods: Quantitative research based on the author's theoretical model and was conducted on a group of 180 Polish SMEs with the use of a structured questionnaire. To verify the hypothesis measures of dispersion as well as correlation were used.

Findings: The share of investments in OC vary at particular growth stages and the highest is in decline stage. Investigated firms invest mostly in 'brand' and 'IT systems'. Investing in OC seems to be important mostly for SMEs that are in the prime stage. In this stage the share of investments in $\mathrm{OC}$ is correlated with almost all performance indicators. It suggests that $\mathrm{OC}$ can be treated as a source of competitive advantage and firms' performance.

Implications \& Recommendations: The appropriate share of investments in particular resources positively impact the effectiveness of decisions aimed at enhancing SMEs growth. Guidelines in what to invest help managers to plan their activities, especially while operating in a rapidly changing environment.

Contribution \& Value Added: The study contributes to the stream of research devoted to SME growth factors. Despite the fact that there already are publications on the impact of particular resources on organisations' success or failure, complex studies, including those concerning Polish SMEs, are much needed.

\begin{tabular}{llll}
\hline Article type: & research paper \\
Keywords: & SMEs; small and medium-sized enterprises; growth models; organi- \\
& zational capital; investments; resources & \\
JEL codes: & L21, L25, L26 & & \\
\hline Received: 21 January 2016 & Revised: 4 July 2016 & Accepted: 31 August 2016 \\
\hline
\end{tabular}

\section{Suggested citation:}

Pauli, U. (2016). Enhancing SMEs' Growth by Investing in Organizational Capital. Entrepreneurial Business and Economics Review, 4(3), 103-116, DOI: http://dx.doi.org/10.15678/EBER.2016.040308 


\section{INTRODUCTION}

Increasing competition among small and medium enterprises (SMEs) and between their large competitors, as well as an opportunity to act on international markets cause that companies operating in SMEs sector have to build their competitive advantage on the basis of resources that cannot be easily imitated by other firms. One of such resources is organizational capital (OC) which consists of processes, procedures, brand creation, management systems and structures. Because it is firm-specific it may play an important role in building sustainable competitive advantage. However, because firms change over their life cycle, the shape of processes and structures has to be modified as well and investments in organizational capital should be made. According to Maritan (2001) there is not much research focusing on the mechanism of building organizational capabilities by investing in resources.

This article is aimed at verifying if there is a relationship between investments in organizational capital and SMEs growth. In the first part a literature review concerning resource-based view of the firm and organisation growth theories is conducted. It is followed by a presentation of a theoretical model and results of conducted research. Conclusions are drawn on the basis of the data gathered from a 179 random sample of Polish SMEs. In the research structured questionnaire was used and correlations between the share of investments in $\mathrm{OC}$ and growth stages were verified. In conclusions main findings, referring to the article's main goal are presented and implications of investing in OC for SMEs growth are summed up.

\section{LITERATURE REVIEW}

\section{Organizational Capital as a Source of SMEs Competitive Advantage}

A firm may achieve and sustain a competitive advantage when it is built on the basis of resources that can be characterised as valuable, rare, inimitable and nonsubstitutable (VRIN attributes) (Barney, 1991). Such an advantage may stem from physical capital resources, human capital but also from organizational capital which is defined as internal processes and systems that refer to planning, coordinating, structure and informal relations among employees (Barney, 1991). On the basis of resource-based view of the firm Galbreath (2005) in his research used more detailed categories referring also to tangible and intangible resources. According to Galbreath's (2005, p. 980) conceptual framework "resources can be divided into:

1. Tangible resources which include (a) financial assets and (b) physical assets.

2. Intangible resources that are assets which include (a) intellectual property assets, (b) organizational assets and (c) reputational assets.

3. Intangible resources that are skills which include capabilities."

In this model organizational assets refer to factors that impact firms' performance and allow to manage all other resources. These assets should be planned and developed as they consist of such important components as structure and human resource policies (Galbreath, 2005). Similarly, Ćwik (2011, p. 35) claims that competitive advantage stems from five fundamental resources that are: 
1. Human resources - especially knowledge, skills, attitudes and abilities;

2. Relational resources - relationships with stakeholders;

3. Tangible resources - real estates, materials, machines;

4. Financial resources - cash, deposits and equities that can be transferred into cash;

5. Organizational resources - that include brand, image, know-how, strategies, procedures and internal systems.

The resource-based-view of the firm focuses on factors that organisations have and may use in order to achieve appropriate level of competitiveness (Eisenhardt \& Martin, 2000). The structure, quality and quantity of these resources as well as the way organisations use them is a foothold for market position. Taking into account SMEs' characteristics it should be added that they have fewer tangible and financial assets than their larger counterparts (Berends, Jelinek, Reymen \& Stultiëns, 2013), which causes that their competitive advantage may stem mostly from intangible assets. Moreover, SMEs' owners do not have an access to many important market analyses and data or do not implement appropriate control systems (Voss \& Brettel, 2013), which make them more vulnerable to environmental changes (Surma, 2010, p. 52). That is why organizational capital which refers to the way firms are organised, to processes they implement and to the schemes they follow, is so important in achieving appropriate level of performance. OC includes tasks that affect firms' functioning and refer to setting goals and developing strategies, planning, defining tasks, coordinating and communicating decisions to employees (Squicciarini \& Le Mouel, 2012, p. 7). It can be divided into structural capital (organizational structure, IT systems and licenses), operational processes capital (procedures, quidelines, methods, schemes) and innovative capital (R\&D activities, patents) (Beyer, 2010, p. 175). On the basis of the definition cited, it is assumed in this study that OC includes brand, IT systems, management systems and know-how that organisation may use in order to achieve competitive performance or act effectively. According to Flamholtz (1995) factors corresponding directly to organizational capital are the foundations of firms' performance. The development of operational systems, management systems and corporate culture impact directly the level of goal achievement. However, the importance of these factors is not the same along firms' lifecycle. That is why, organisations should analyse changes in their functioning and analyse what changes they should implement and in which components of organizational capital they should invest.

\section{Organisations' Growth Theories}

Organisations' growth is a widely discussed issue in scientific papers. Many researchers have developed their own models presenting the path organisations follow from their initial phase. The multiplicity of approaches stems mostly from the diversity of SMEs which operate in different branches and on different markets. Moreover, the number of such enterprises makes it difficult to capture similarities which makes researchers try to generalise focusing on different issues. Such models characterise precisely changes that appear in the market position, size, level of incomes, but also in the shape and complexity of internal processes and systems. According to Hugo and Garnsey (2005) firms' growth is very often analysed with the use of firm size, market share and sales revenue figures. Internal changes and resources development are less frequently discussed. That 
is why, in this part, examples of most commonly cited organisation growth models are presented through the lens of changes in internal systems.

One of the most commonly cited model developed by Churchil and Lewis (1983) consists of five stages: existence, survival, success, take-off and resource maturity. The authors claim that SMEs growth is determined by factors related to the enterprise and to the owner. Those referring to the enterprise directly correspond to OC because they consist of management style, organizational structure, extent of formal systems, major strategic goals (Churchil \& Lewis, 1983). As the organisation grows they have to introduce operating schemes, control systems, build their brand, design communication channels and plan their goals. Moreover, changes in organizational structure should be implemented and SMEs should switch from simple, owner-managed firms into decentralised, and functionally divided ones.

In the model of Scott and Bruce (1987) (similarly to Churchil \& Lewis, 1983) five stages were defined: inception, survival, growth, expansion and maturity. In each of these stages, requirements for change in internal processes were drawn. In the beginning, in the inception, firms should concentrate mostly on formalizing basic processes and financial issues. Following their growth they should change their managing style by delegating supervisory tasks and focusing on coordination. While SMEs grow the pressure for implementing effective information and communication systems appears, and advanced control systems should be introduced. In the following stage SMEs should focus on administrative issues enabling to control and coordinate wide and complex processes, but firms should be aware of possible red-tape crisis. In the mature stages organisations should also pay more attention to marketing and brand creation, which can be important in sustaining the market position (Scott \& Bruce, 1987).

Hanks, Watson, Jansen and Chandler (1993) based their model on detailed analyses of a number of organizational levels, specialised functions, formalization and average percentage of sales revenues and employment growth. In the subsequent stages that are: start-up, expansion, maturity, diversification, the number of: organizational levels vary from 2.2 to 5.7; specialised functions from 1.5 to 15.3 ; sales revenue growth vary from $91 \%$ (in start-ups), $297 \%$ (in expansion) to $37 \%$ in diversification (Hanks et al., 1993). All these figures clearly state that there are ongoing changes in internal systems and processes on the growth path of enterprises.

Greiner (1998) built his model on the basis of crises that refer to managerial problems. These problems are connected with changes on markets as well as with the increasing size and complexity of firms. In the model five stages were described (creativity, direction, delegation, coordination, collaboration) and each of these stages forces the owner to implement changes in management style, communication system, decision making, planning and organizational structure.

The development of internal systems and processes is also discussed or can be drawn from the models of Jackson and Morgan (1982), Mintzberg (1984), Adizes (2004), Matejun (2013), Miller and Friensen (2014). Despite the fact that there are many differences in organisations' growth models, that stem from the approach adopted by the authors, each of them presents a coherent model of organisation features at subsequent stages. On the basis of such characteristics a unified model presenting changes in the internal systems of the SMEs can be drawn. According to Floren (2011) a firm's growth 
extorts changes in the structure, planning and formalization level. Such a situation cause a dilemma whether to remain small and flexible or to introduce more structuralised solutions in order to reach higher effectiveness. Nevertheless, SMEs should invest in organizational capital in order to create conditions that enable reaching desired levels of performance.

\section{Theoretical Model and Hypotheses}

On the basis of organisations' growth theories it is assumed that over their life cycle SMEs follow a path that consists of five main stages: survival, take-off, prime, maturity and decline. In each of the stages a combination of resources, crucial for achieving goals and reaching appropriate level of performance, can be described. One of these resources is organizational capital which refers to the scope, extent and complexity of internal systems. The way SMEs are organised and how they run their internal processes is crucial due to their limited financial and tangible resources. If internal systems are implemented properly organisations can achieve superior performance. The theoretical foundation of the research is presented in Figure 1.
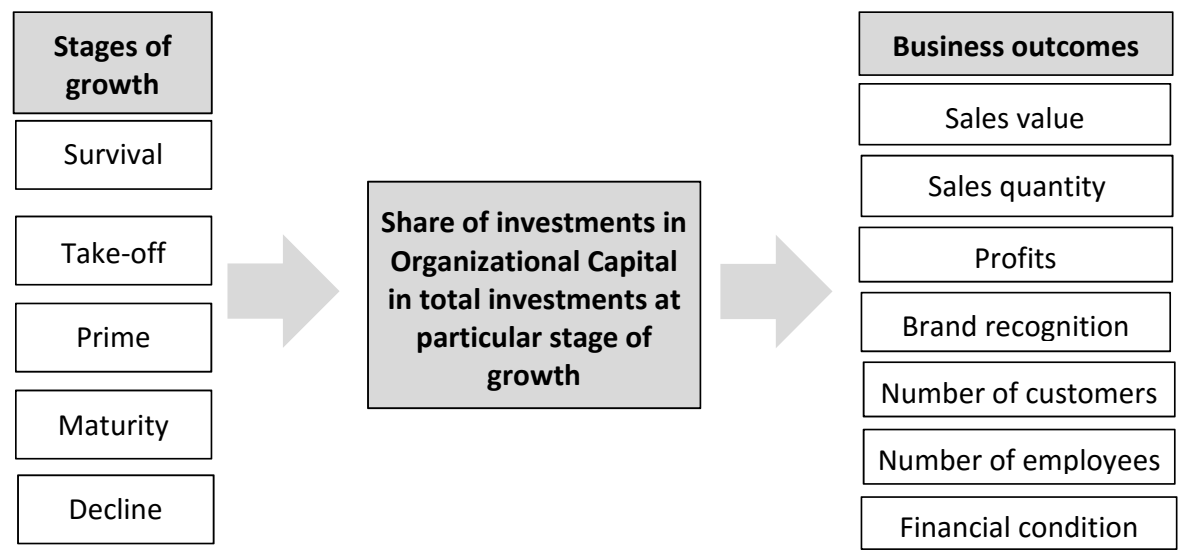

Figure 1. Impact of the share of organizational capital investments on business outcomes at growth stages

Source: own research.

According to the developed model SMEs set different goals at particular stages of their growth which refer to their potential and market position. This is why they require different resources in order to achieve desired performance. Thus, it can be hypothesized that:

H1: The share of investments in organizational capital in total investments differs in subsequent growth stages.

As SMEs grow they require different solutions enhancing their efficiency and they have to adapt to changing market conditions. Thus, the structure of investments in organizational capital should not be the same at all stages. It can be hypothesized that:

H2: The structure of investments in particular components of organizational capital differs in subsequent growth stages. 
Because the shape, extent and complexity of internal processes affect efficiency it will also impact SMEs business outcomes. Thus, it can be hypothesized that:

H3: The share of investments in organizational capital within total investments impact SMEs' business outcomes at particular growth stages.

Business outcomes can be measured by the means of sales value, sales quantity, profits, brand recognition, number of customers, and overall financial condition.

\section{MATERIAL AND METHODS}

The research was conducted on a group of 470 Polish SMEs in the years 2014 and 2015. In the study the definition of SMEs provided by the Polish government (that refers to EU regulations) was implied. Only the organisations that employ between 9 and 249 employees, and have incomes up to 43 million euros (Ustawa ..., 2004) were taken into account. Following Churchill and Lewis (1983) and Hanks et al. (1993) it was assumed in the study that SMEs may go through all the subsequent stages of growth, not becoming large organisation. It implies that even a small firm may face threats referring to decline stage, because of shrinking market or mismatch between managerial decisions and market conditions.

Respondents were chosen randomly from a database consisting of 1950 items, which had been built with the use of the information from Polish Statistical Office. While selecting SMEs, stratified sampling, including geographical density of companies in regions was applied. Despite the fact that the sample corresponded to the number of companies in a particular region, it was not representative because the number of investigated companies did not correlate with the total number of SMEs in Poland. While collecting data, PAPI technique was used and the owners or managers were asked to answer questions listed in a questionnaire. During the interviews, some respondents refused to give answers to particular questions concerning the value of investments in particular resources, the sales value, profits or business outcomes. That is why, in this paper information from only 180 questionnaires was used. In most cases investigated SMEs had only one profile and services (43\%) were dominant. The share of companies that act in the production and sales branch was similar (Table 1 ).

The first step of analytical procedure was aimed at evaluating the growth stage. On the basis of literature study and developed model, indicators of the following eight areas: products and services, distribution, technology, management, finance, customers, brand and relations with stakeholders, were investigated. For each area three to six questions were asked, giving respondents a possibility to choose an answer corresponding to the particular stage of growth. Provided options, were based on (1) quantity (for example the number of introduced innovations, range of products and services, number of distribution channels, and facilities for customers), (2) formality/complexity (for example in the 'management system' area the scope of answers to the question concerning job description was from 'we do not have job descriptions or tasks specifications', to 'we have detailed job descriptions, formalized functional relationships, and listed tasks executed while fulfilling roles', (3) relationships with stakeholders (for example, share of occasional and regular customers, stability in cooperation with suppliers and subcontractors, involvement in CSR activities, and cooperation with partners). On the basis of pro- 
vided answers and with the use of modal value the stage of growth was described on a five-grade scale where ' 1 ' stands for 'survival', ' 2 ' for 'take off', ' 3 ' for 'prime', '4' for 'maturity', and ' 5 ' for 'decline'. The share of companies in particular growth stages is presented in Table 1.

Table 1. Sample characteristics

\begin{tabular}{|c|c|c|c|c|c|c|c|c|c|}
\hline \multirow{2}{*}{$\begin{array}{l}\text { Profile } \\
\text { (in \%) }\end{array}$} & $\begin{array}{l}\text { Services } \\
\text { (A) }\end{array}$ & \multicolumn{2}{|c|}{$\begin{array}{l}\text { Production } \\
\text { (B) }\end{array}$} & \multicolumn{2}{|c|}{$\begin{array}{l}\text { Sales } \\
\text { (C) }\end{array}$} & $A+B+C$ & $A+B$ & $A+C$ & $B+C$ \\
\hline & 43 & \multicolumn{2}{|c|}{17} & & 15 & 5 & 4 & 6 & 9 \\
\hline \multirow{2}{*}{$\begin{array}{c}\text { Market } \\
\text { (in \%) }\end{array}$} & Local & \multirow{2}{*}{$\frac{\text { Regional }}{29}$} & \multicolumn{2}{|c|}{ National } & \multicolumn{2}{|c|}{ International } & \multicolumn{3}{|c|}{ no answers } \\
\hline & 31 & & \multicolumn{2}{|c|}{18} & \multicolumn{2}{|c|}{17} & \multicolumn{3}{|c|}{5} \\
\hline \multirow{2}{*}{$\begin{array}{c}\text { Growth } \\
\text { stage (in \%) }\end{array}$} & \multicolumn{2}{|c|}{ Survival } & \multicolumn{2}{|c|}{ Take-off } & \multicolumn{2}{|c|}{ Prime } & Maturity & \multicolumn{2}{|c|}{ Decline } \\
\hline & \multicolumn{2}{|l|}{16} & \multicolumn{2}{|l|}{34} & \multicolumn{2}{|c|}{28} & 16 & \multicolumn{2}{|c|}{5} \\
\hline
\end{tabular}

Source: own elaboration on the basis of data gathered.

The next step was to calculate the mean value of the share of investments in organizational capital. The data was divided into four main components: brand, know-how, IT systems and management systems. Respondents were asked to provide information about monetary value of such investments. However, they were also informed that if some activities connected with a particular component are executed by employees and are treated/regarded as an investment, respondents should provide estimated cost of such investments by calculating them on the basis of employees' salary and time spent on the activity. The share of investments in organizational capital was calculated by summing up all expenditures and dividing them by the value of all investments made by a particular company. As a result the share and the structure of investments in organizational capital was calculated. The share of investments in organizational capital in total investments represented by a value falling into a $<0 ; 1>$ range is presented in Figure 2 . It was followed by analyses of the structure of investments in organizational capital at subsequent stages, which is presented in Figure 3.

The last stage of analytical procedure was testing the relationship between: (i) the share of investments in organizational capital and the stage of growth, (ii) the structure of OC investments and the stage of growth, and (iii) between the share of investments in $\mathrm{OC}$ and business outcomes. As indicators of performance nine variables, referring to: (a) quantity of products' sale, (b) quantity of services' sale, (c) value of products' sale, (d) value of services' sale, (e) profits, (f) number of customers, (g) number of employees, (h) overall financial condition and (i) brand recognition were chosen. To evaluate performance a five-grade scale was used. On the basis of business outcomes respondents achieved in the last three years, they were to specify if a given indicator: definitely decreased, decreased, remained stable, increased or definitely increased. As the variables 'stage of growth' as well as 'business outcomes' were discrete (represented by values 1-5), it was necessary to rank the variable 'share of investments in organizational capital' to verify the correlation with the use of the Spearman method. Rank ' 1 ' was granted to companies with the lowest share of investments in organizational capital.

All interviews were conducted in March and April which made it possible to provide up-to-date answers based on previous year annual statements. The results of correlation testing are presented in Table 3. However, due to the fact that only nine companies fell into the group of companies in the decline stage. 


\section{RESULTS AND DISCUSSION}

\section{Share of OC Investments in Total Investments}

The average share of investments in OC in SMEs is almost at the level of one third of all investments expenditures (Figure 2). Improving internal systems and procedures is perceived by organisations as an important activity enhancing their performance. More detailed analyses of the $\mathrm{OC}$ investments at growth stages shows that starting from the take-off the share of spending on internal development is rising.

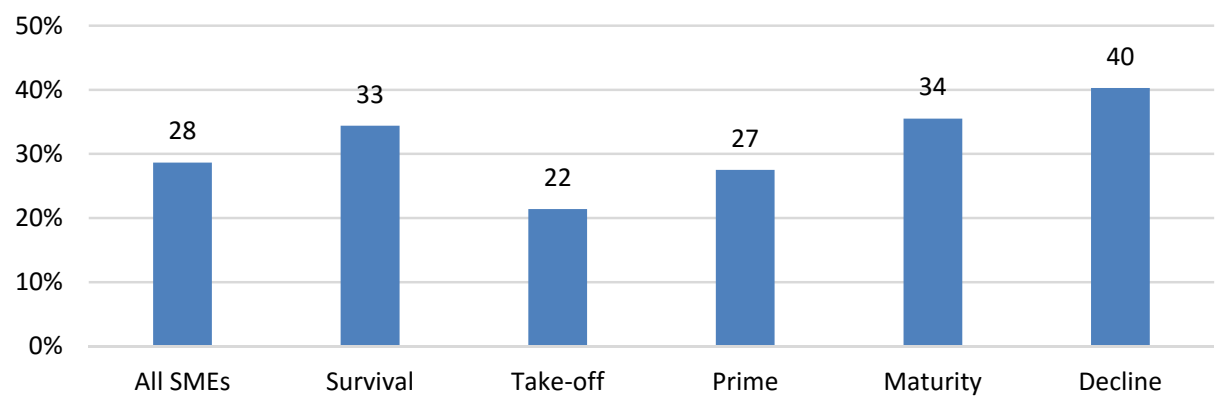

Figure 2. The share of investments in $\mathrm{OC}$ in total investments at subsequent growth stages (in \%) $(n=180)$

Source: own research.

However, it should be added that companies at the survival stage allocate more than one third of their funds in OC. Such a high share at the initial stage may stem from the necessity to organise all basic processes enabling SMEs to exist on the market and run the business. At the take-off stage, when companies focus mostly on market and search for selling opportunities, more funds are spent on other activities such as building relations with customers and business partners or investing in tangible resources. Organisations which achieve an appropriate market position at the take-off start their rapid growth that can be observed in prime stage. An increasing number of customers, new markets and business partners cause that there is a need to modify and upgrade processes and the way SMEs are managed. This is why the share of investments in OC in total expenditures is increasing. Following the growth path at the maturity stage firms are stable, with a good market position so they can pay less attention to external issues and concentrate on internal ones which generates a higher level of investments in OC. At the decline stage, as profits and market share are decreasing, companies try to reorganise their processes in order to cut off costs and reduce unnecessary activities. Such actions require funds for reengineering business processes. Despite the fact that the share of OC investments and its changes in investigated SMEs are in accordance with theoretical foundations the correlation between this variable and stage of growth was not verified statistically. Thus, it should be concluded that the first hypothesis is not supported. 


\section{Structure of OC Investments}

The structure of investments in $O C$ changes at subsequent stages. Initially, SMEs invest mostly in IT systems and in the brand (Figure 3 and Table 2). Following the growth path it can be seen that the share of investments in IT systems decreases while the ratio of brand investments rises. The correlation between these two areas and growth stages is supported statistically (Table 2). There are also changes in the share of other areas of investments. Taking into account management systems, it can be seen that SMEs do not invest in them almost at all at the survival stage. It can stem from a belief that owners or managers are able to cope with all duties or from the low complexity of internal processes that do not require advanced tools or methods. At the two subsequent stages (takeoff and prime) changes in SMEs position and scope of activities may initiate investments that enhance the quality of management processes. Introduced solutions at prime stage may fit organisations, and make the share of such investments lower in the last two stages.

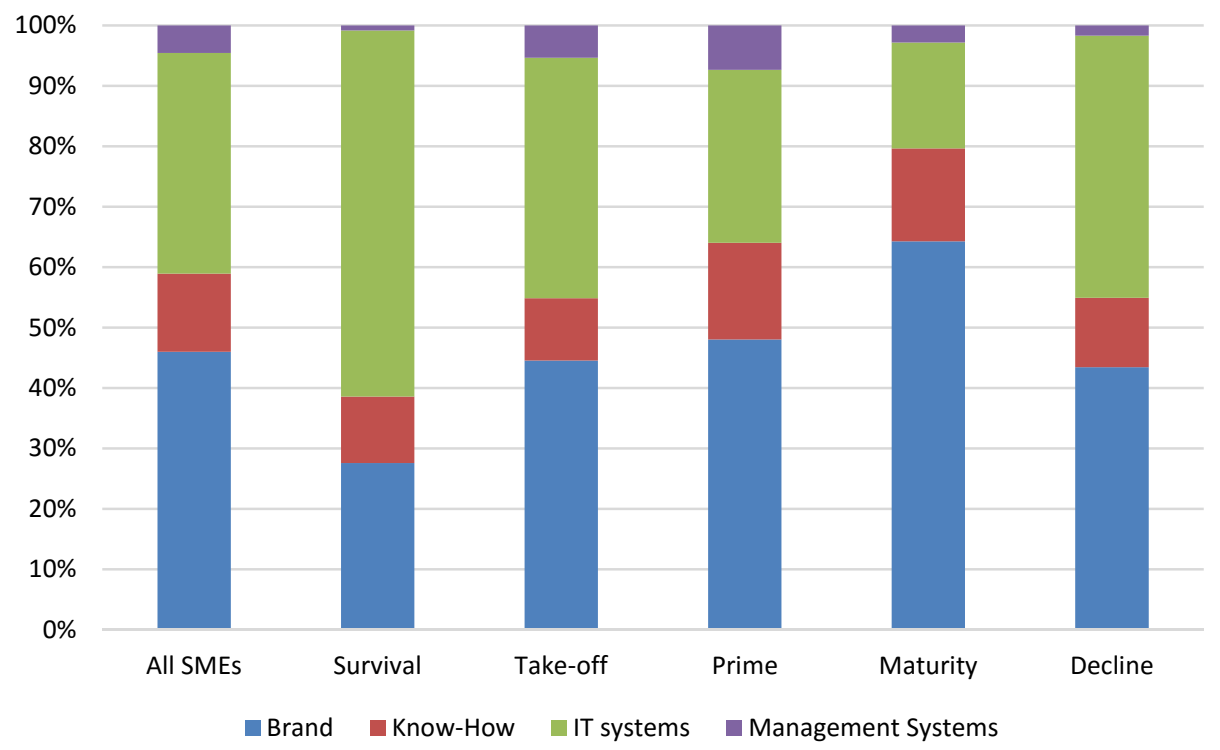

Figure 3. The structure of investments in OC at subsequent growth stages ( $n=180$ ) Source: own research.

The share of investments in know-how is at almost the same level at survival, takeoff and decline stage (Figure 3 and Table 2). However, SMEs seem to invest more in know-how at prime and maturity. It may results from the market position and firms' potential. At the prime stage companies achieve high level of incomes, profits and their market share increases rapidly. It makes them search for new products or services and they become more eager to invest in know-how. Similar causes may refer to maturity stage. A stable market position and brand recognition create conditions in which companies willing to renew their offer invest in know-how which helps them launch new products or services. In some cases higher share of investments in know-how may also stem 
from the lowering level of incomes and shrinking markets. Managers or owners of SMEs, invest in new technologies or new solutions and try to prevent organisations from falling into the decline stage.

On the basis of conducted analyses it can be concluded that the structure of investments in organizational capital varies in accordance with a particular stage of growth. Due to the fact that not all correlations were verified statistically it can be concluded that the second hypothesis is partly supported.

Table 2. Structure of OC investments at subsequent stages (as a percent of total OC investments)

\begin{tabular}{|l|c|c|c|c|c|c|}
\hline \multicolumn{1}{|c|}{ Area of investments/ Growth stage } & All SMEs & Survival & Take-off & Prime & Maturity & Decline \\
\hline Brand $\left(0.241828^{*}\right)$ & 46.0 & 27.6 & 44.5 & 48.0 & 64.3 & 43.4 \\
\hline Know-How & 12.9 & 11.0 & 10.3 & 16.0 & 15.4 & 11.5 \\
\hline IT systems (-0.254671*) & 36.5 & 60.6 & 39.8 & 28.6 & 17.5 & 43.4 \\
\hline Management systems & 4.6 & 0.8 & 5.3 & 7.3 & 2.8 & 1.7 \\
\hline
\end{tabular}

* Spearman's Rank Correlation significance for $p=0,05$

Source: own research.

\section{OC Investments and Business Outcomes}

Organizational capital can be treated as a source of sustainable competitive advantage because of its VRIN attributes. Thus, investments in OC should impact SMEs' business outcomes. According to the model to evaluate the relationship between such investments and business outcomes the changes in nine performance indicators were analysed. In Table 3 the correlations between the share of investments in OC and performance indicators are presented. In the cases where the relationship is verified statistically (with $p=0.05$ ) the value of the coefficient appears in the fourth column.

Table 3. Correlation between share of investments in $\mathrm{OC}$ and business outcomes indicators

\begin{tabular}{|l|c|c|c|c|c|c|}
\hline \multicolumn{1}{|c|}{ Variables } & $\begin{array}{c}\text { All SMEs } \\
(\boldsymbol{n}=\mathbf{1 8 0})\end{array}$ & $\begin{array}{c}\text { Survival } \\
\text { stage } \\
(\boldsymbol{n}=\mathbf{2 8})\end{array}$ & $\begin{array}{c}\text { Take-off } \\
\text { stage } \\
(\boldsymbol{n}=\mathbf{4 8})\end{array}$ & $\begin{array}{c}\text { Prime } \\
\text { stage } \\
(\boldsymbol{n}=\mathbf{4 8})\end{array}$ & $\begin{array}{c}\text { Maturity } \\
\text { stage } \\
(\boldsymbol{n}=\mathbf{2 8})\end{array}$ & $\begin{array}{c}\text { Decline } \\
\text { stage } \\
(\boldsymbol{n}=\mathbf{9})\end{array}$ \\
\hline Share of investments in OC & 1 & 1 & 1 & 1 & 1 & 1 \\
\hline Quantity of products' sale & - & - & - & $0.333449^{*}$ & - & - \\
\hline Quantity of services' sale & - & - & - & - & - & - \\
\hline Value of products' sale & - & - & - & $0.337769 *$ & - & - \\
\hline Value of services' sale & - & - & - & $0.295658^{*}$ & - & - \\
\hline Profits & - & - & - & $0.366323^{*}$ & $0.366839^{*}$ & $0.366839^{*}$ \\
\hline Number of customers & - & - & - & $0.392860^{*}$ & - & - \\
\hline Number of employees & - & - & - & - & - & - \\
\hline Overall financial condition & $0.17802^{*}$ & - & - & $0.551985^{*}$ & $0.387029^{*}$ & $0.387029^{*}$ \\
\hline Brand recognition & $0.20429^{*}$ & - & - & $0.498291^{*}$ & - & - \\
\hline
\end{tabular}

* Spearman's Rank Correlation significant codes: 0.05

Source: own calculations in Statistica.

Taking into account all companies (regardless of the growth stage) there is a correlation only between the share of investments in $\mathrm{OC}$ and the overall financial condition or brand recognition. Despite the fact that the relationship is supported in the case of two out of nine indicators it can be stated that the overall financial condition seems to be the 
most important for SMEs. In the case of all other indicators other resources, for example tangible assets, human capital or relational capital, have to be of higher importance.

There is no correlation between the share of OC investments in total investments and business outcomes in companies in the survival stage. Such organisations are exposed to so many environmental threats and have so few resources that the relationship between actions taken and performance is not constituted.

In the take-off and maturity stage there is a relationship between OC investments and one performance indicator. When SMEs are growing investments in OC are negatively correlated with value of products' sale. The requirements of shaping the way the business is organised and managed after the survival stage, cause that SMEs have to spend more funds on internal processes. At the same time the brand is not widely recognised yet and the number of customers is not increasing relatively to the owners' expectations. It may cause that the value of products' sale is much lower than expected.

At the maturity stage $\mathrm{OC}$ investments correlate with profits. SMEs have a stable market position and their products or services meet customers' expectations. Actions taken in order to improve or modify internal processes are aimed at increasing efficiency which may result in lowering general costs. Lower costs and high sale value may result in profits rise.

The highest impact of $O C$ investments on business outcomes can be observed at the prime stage. The correlation is statistically important in the case of six out of nine indicators. The higher the share of $\mathrm{OC}$ investments is the more frequently an increase in value of products and services sale can be observed. There is also a rise in the number of customers and brand recognition which may result from introducing marketing and promotion schemes and processes. What is more, there is a positive relationship between the share of $\mathrm{OC}$ investments and profits or overall financial condition. Such a correlation may stem both from better brand recognition as well as from increasing efficiency of internal processes and management systems.

On the basis of conducted analysis it can be concluded that the share of investments in OC impacts business outcomes mostly at the prime stage. At other stages there is no correlation or OC investments impact only one indicator. Thus, it can be stated that the third hypothesis is partly supported.

\section{CONCLUSIONS}

Organizational capital which is firm specific, difficult to imitate and substitute is treated as a source of sustainable competitive advantage. In the case of SMEs which have fewer financial and tangible assets than their large competitors, such a resource can play a crucial role in achieving a success. Despite the fact that firms build their organizational capital from the initial phase by changing the way they act and by implementing modifications in internal processes, it can be stated (on the basis of conducted research) that it does not have the same impact on business outcomes at every stage of SMEs growth.

Investments in organizational capital seem to be the most important at the prime stage in which SMEs face a rapid growth. Lack of investments in OC may create constraints that lower SMEs' potential and cause a decrease in their performance. Thus, it is very important for managers and owners to provide conditions for incremental growth at this stage. It is also important that in general, investments in OC impact the overall fi- 
nancial condition and brand recognition. Taking into account all investigated SMEs, regardless of their stage of growth, size and profile, the correlation between these variables was statistically verified. It suggests that $\mathrm{OC}$ can be treated as a source of competitive advantage and firms' performance.

Despite the fact that there was no statistical correlation between the share of OC investments and the particular stage of growth, SMEs seem to follow schemes presented in the theory of organisation growth. The share of OC investments in total investments is high at the survival stage which results from the necessity to initiate all activities. At the take-off stage it drops and investments in other resources, for example tangible assets or relationships with stakeholders, are made. Starting from the take-off stage there is an increase in the share of $\mathrm{OC}$ investments which is associated with the rising complexity of internal processes and the size of the firm. Such findings might be important for managers and owners because of their applicability. They should make their investment decisions on the basis of an in-depth analysis of the firms' functioning and not to implement the same schemes of investments all the time.

On the basis of conducted research it should also be concluded that managers and owners should invest more in the brand on subsequent stages. The more developed an organisation is the more attention should be paid to promotion and building the organisation's image. Diverse conclusion could be drawn while taking into account IT systems. The share of IT investments decreases on subsequent stages. It can be concluded that appropriate investments at the initial stages can support SMEs functioning throughout their lifecycle.

Despite the fact that the research provides data to draw conclusions concerning investments in OC and SMEs growth, it has several limitations. First of all, the sample consists of only Polish SMEs which makes it impossible to generalize about the findings and apply them also to companies that operate in other countries. Secondly, taking into account the total number of existing SMEs, the sample size of 470 companies initially interviewed, and 180 finally taken into account for statistical analyses, is relatively small. Although SMEs were selected randomly from a database including 1950 items, the results cannot be applied as a representative because of three main reasons: (i) the sample consists of Polish enterprises only, (ii) the sample is relatively small in comparison to the number of existing SMEs, (iii) the sample was not homogenous - SMEs operating in different branches and having different profiles were analysed. Thirdly, in the sample SMEs in their decline stage were underrepresented which made it necessary to implement stratified sampling in the further study. Fourthly, information concerning investment expenditures referred only to the data included in financial statements for 2013 or 2014. In order to analyse the impact of investments on performance and growth it is necessary to compare collected data with those referring to a longer scope of time, especially whilst analysing investments in organizational capital. Finally, some changes in methodology can be implemented. They may refer to evaluation of a growth stage, as a modal value could not be sufficient enough to classify particular SME into an adequate stage of growth. Moreover, some econometrical models describing relationships between investments in $\mathrm{OC}$ and performance could be applied in further research. Having verified statistical correlation between investments in $\mathrm{OC}$ and some performance indicators at 
particular growth stages, despite the limitations the research is a foothold for further studies that could be conducted in more homogenous groups of SMEs.

\section{REFERENCES}

Adizes, I. (2004). Managing corporate lifecycles. Carpinieria: Adizes Institute Publications.

Barney, J.B. (1991). Firm resources and sustained competitive advantage. Journal of Management, 17(1), 99-120.

Bayer, K. (2010). Kapitał intelektualny jako zasób przedsiębiorstwa - koncepcja i modele zarządzania (intellectual capital as a resource in enterprise - conception and models of management). Studia i Prace WNEiZ, 17, 171-182.

Berends, H., Jelinek, M., Reymen, I., \& Stultiëns, R. (2014). Product Innovation Processes in Small Firms: Combining Entrepreneurial Effectuation and Managerial Causation. Journal of Product Innovation Management, 31(3), 616-635.

Churchil, N.C., \& Lewis, V.L. (1983). The five stages of small business growth. Harvard Business Review, 61(3), 30-50.

Ćwik, K. (2011). Zachowania strategiczne małych przedsiębiorstw i ich uwarunkowania w aspekcie teoretycznym (Strategic behaviours of SMEs and their determinants in the theoretical aspect). In S. Lachiewicz, \& M. Matejun (Eds.), Zarzqdzanie rozwojem małych i średnich przedsiębiorstw (SMEs growth management) (pp. 26-43). Warszawa: Oficyna Wolters Kluwer Business.

Eisenhardt, K.M., \& Martin, J.A. (2000). Dynamic capabilities: what are they? Strategic Management Journal, 21(10-11), 1105-1121.

Flamholtz, E. (1995). Managing Organizational Transitions: Implications For Corporate and Human Resource Management. European Management Journal, 13(1), 39-51.

Floren, H. (2011). Organising small-firm growth. In S.-Å. Hörte (Ed.), Research on Technology, Innovation and Marketing Management 2009-2011: Introducing the Research Area of Innovation Science (pp. 117-133). Halmstad: Högskolan i Halmstad.

Galbreath, J. (2005). Which resources matter the most to firm success? An exploratory study of resource-based theory. Technovation, 25(9), 979-987.

Greiner, L.E. (1998). Evolution and revolution as organizations growth. Harvard Business Review, 76(3), 55-68.

Hanks, S., Watson, C., Jansen, E., \& Chandler, G. (1993). Tightening the life-cycle construct: A taxonomic study of growth stage configurations in high-technology organisations. Entrepreneurship Theory and Practice, 18(2), 5-29.

Hugo, O., \& Garnsey, E. (2005). Problem-Solving and Competence Creation in the Early Development of New Firms. Managerial and Decision Economics, 26(2), 139-148.

Jackson, J.H., \& Morgan, C.P. (1982). Organization Theory. A Macro Perspective for Management. London: Prentice Hall.

Maritan, C.A. (2001). Capital Investments as investing in organizational capabilities: an empirically grounded process model. The Academy of management Journal, 44(3), 513-531.

Matejun, M. (2013). Instruments Supporting Development in the Life Cycle of Small and MediumSized Enterprises. International Journal of Economic Sciences, II(1), 40-60.

Miller, D., \& Friessen, P.H. (2014). A longitudinal Study of the corporate lifecycles. Management Science, 30(10), 1161-1183. 
Mintzberg, H. (1984). Power and organization life cycles. Academy of Management Review, 9(2), 207-224.

Scott, M., \& Bruce, R. (1987). Five stages of growth in small business. Long Range planning, 20(3), 45-52.

Squicciarini, M., \& Le Mouel, M. (2012). Defining and Measuring Investment in Organizational Capital: Using US Microdata to Develop a Task-based Approach. OECD Science, Technology and Industry Working Papers, 2012/05. Paris: OECD Publishing. doi: http://dx.doi.org/10.1787/5k92n2t3045b-en

Surma, J. (2010). Rola analogii w podejmowaniu decyzji w zarzqdzaniu strategicznym małymi I średnimi przedsiębiorstwami. Warszawa: Oficyna Wydawnicza SGH.

Ustawa z dnia 2 lipca 2004 r. o swobodzie działalności gospodarczej (Economic Freedom Act), Dz. U. Nr 173, poz. 1807.

Voss, U., \& Brettel, M. (2014). The Effectiveness of Management Control in Small Firms: Perspectives from Resource Dependence Theory. Journal of Small Business Management, 52(3), 569587.

\section{Author}

\section{Urban Pauli}

Adjunct (Assistant Professor) in the Department of Human Capital Management at Cracow University of Economics. PhD in Management (Cracow University of Economics).

Correspondence to: $\mathrm{Dr}$ Urban Pauli; Cracow University of Economics; Department of Human Capital Management; ul. Rakowicka 27, 31-510 Kraków, Poland; e-mail: urban.pauli@uek.krakow.pl

\section{Acknowledgements and Financial Disclosure}

The article came into being within the project no. DEC-2012/07/d/HS4/00789 entitled 'Effectiveness of SMEs' investments in development ' financed by Polish National Science Center, conducted by Urban Pauli in the years 2013-2016.

\section{Copyright and License}

This article is published under the terms of the Creative Commons Attribution - NonCommercial - NoDerivs (CC BY-NC-ND 3.0) License http://creativecommons.org/licenses/by-nc-nd/3.0/ 